\title{
CONSTITUTIONAL REVISION AND PARTY CIRCLE BILLS
}

\author{
KENNETH C. SeARs*
}

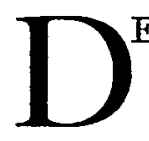

EMANDS for a constitutional convention to revise the I870 Tllinois constitution started as early as $1893 .{ }^{x}$ The contents of the defeated new constitution in $1922^{2}$ disclose that those who framed it-conservative men they were-believed that our present constitution needed a general revision. Since then there has been an endless discussion of the means by which the citizens of Illinois can secure a modern constitution, an efficient government, and equal justice for all. ${ }^{3}$ In I 944 this assertion was made by way of a challenge and the challenge has never been accepted.

Illinois, everything considered, is in the worst position of any state in the Union. A majority of its voters who have any ideas to express have frequently shown that they think that their constitution is in need of a general revision. But, owing to the rigid and restrictive provisions for a revision or amendment, Illinois flounders around in its constitutional morass. It is a ridiculous spectacle for what is supposed to be one of the great states in the United States. Only one judgment can be uttered: Illinois has been politically backward and heaven alone knows when it will become ashamed of itself and exhibit political astuteness. There are ways out of the morass whenever

* Professor of Law, University of Chicago.

${ }^{2} 5$ Centennial History of Illinois I9o (r920). See also the report of a committee of the Illinois State Bar Association in Igo2, which concluded that a constitutional convention "at this time would be desirable and expedient." Proceedings of Ill. State Bar Ass'n, Part 2, I4I-I 59 (I9O2).

$\approx$ I IIl. Ann. Stat. (Smith-Hurd, x930) 387-420.

3 See, inter alia, Ill. Constitutional Convention bull. 05-1209 (I920); Governor Henry Horner's Inaugural Address, Ill. S. Jour., at 47-50 (r933); Illinois Legislative Reference Bureau, The Constitution of Illinois (r934); Report of the City Club of Chicago, The Need for a Constitutional Convention (1934); Thompson and Clarke, Shall We Have a Constitutional Convention? I6 Chicago Bar Record No. I, 9 (1934); Sears, The Need for a Constitutional Convention, I6 Chicago Bar Record No. I, 26 (x934); Powell, A Plan for Facilitating Constitutional Amendment in Illinois, 30 III. L. Rev. 59 (1935); Sears, Voting on Constitutional Conventions and Amendments, 2 Univ. Chi. L. Rev. 612 (1935); Illinois-A Descriptive and Historical Guide 89-92 (1939); Report of Illinois Legislative Council, Problems of Constitutional Revision in Illinois (I94I); C.I.O. Legislative Guide (March 5, I945); Proposed Constitutional Convention, 26 Chicago Bar Record 257 (x943); Akers, A New Constitution for Illinois? (1945); The City Club Bulletin (Jan. 29, 1945); Report of Committee on Organic Law and Legislation of Illinois Post-War Planning Commission, An Imperative Task (1945); Report of Chicago City Council Committee on Consolidation, Reorganization, and Taxation (Dec., 1946). 
Illinois secures the political leadership that can overcome the forces that believe in a relatively static society. 4

\section{URGENT REFORMS}

It has been one of the favorite techniques of the Chicago Tribune to bait those who would reform the Illinois constitution by asking them to specify the reforms which they desire. ${ }^{5}$ Many of those who advocate the calling of a constitutional convention have said: "Do not fall into that trap; merely reply that the voters have a right to say whether they wish to have a convention; and that the General Assembly should submit the proposition to a vote if there is a substantial demand for a convention."

Such a response may be what is known as politically smart. But it appears to be less than frank and less than logical. The burden is upon those who advocate a convention to make at least a prima facie showing to the legislators that a convention is needed. Furthermore, there should be a plan to accomplish desirable reforms and that plan should be common to enough voters to make it likely that a constitutional convention would be a worthy accomplishment. The majority of those voting on a convention proposal should be convinced of that much.

The Chicago Tribune has also stated that advocates of a constitutional convention for Illinois have never stated what they wanted. ${ }^{7}$ This was not true of many advocates and it is believed that the Tribune knew that this accusation was not generally true. In fact, the Tribune itself early ad-

4 Sears and Laughlin, A Study in Constitutional Rigidity, Io Univ. Chi. L. Rev. I42 (1943), II Univ. Chi. L. Rev. 374, 439 (I944).

$s$ Editorial, A Fraud Defeated, Chicago Tribune (July 28, r945). Cf. letter, part of which was not printed, by the author in Voice of the People, Chicago Tribune (Aug. 3, 1945); editorial, Mayor Kelly Is Smart, Chicago Tribune (April 16, 1945) ("Nobody knows what is back of the proposal [for a constitutional convention] aside from the CIO, which is its most vociferous proponent."); news item, Chicago Tribune, p. I2 (March 18, 1945) ("H. I. Green of Urbana could get no specific answer to his question, 'What is the matter with the 1870 constitution?" "). This latter item was an exhibition of real crust, since Mr. Green admitted that he was one of the delegates who drafted and then sought to obtain the ratification of the 1922 constitution.

${ }^{6}$ Such was the attitude of some of those who urged a constitutional convention proposal in 1945. They acted upon the advice of at least one legislative leader who was strongly in favor of a convention.

7 Editorial, What Kind of a Constitutional Convention? Chicago Tribune (Oct. 18, 1934); editorial, The State Constitution, Chicago Tribune (Feb. 26, 1945); editorial, For the Gateway Amendment, Chicago Tribune (Oct. 6, 1946) ("Those who have been clamoring for a constitutional convention have never been candid. Their real aim has been to socialize the economy of the state. ....").

During the 1945 session of the Illinois General Assembly, Representative James O. Monroe used the same tactics. He introduced a resolution calling upon the Governor to give a detailed and comprehensive statement of the reforms needed, particularly with reference to reapportionment. Then he set forth his opposition to a constitutional convention at length in the East St. Louis Journal for March 25, 1945. He failed to explain why he, as Senator James O. Monroe, voted for a constitutional convention proposal in I933. See Ill. S. Jour., at 295 (1933). 
vocated a convention ${ }^{8}$ and very strongly supported the proposal for a convention in I9I8. ${ }^{9}$ However, after the first World War and after Robert $R$. McCormick became the supreme policy-maker, the Tribune has consistently opposed a convention. Even so, it has favored rather casually a few amendments that would not disturb a fundamentally stand-pat policy. ${ }^{\mathrm{I}}{ }^{\circ}$

It seems safe to predict that if Illinois ever obtains a convention there is hardly a clause in the present constitution that will not be reconsidered. Article I on "Boundaries" is presumably satisfactory. Otherwise, one of the main problems will be this: Since there are so many desirable changes, shall a generally revised constitution be submitted to the voters as a single proposition or shall a series of revised articles and sections be submitted as separate propositions?

Article.II-Bill of Rights-is something less than a divine inspiration. For example, some states no longer require a unanimous verdict from a trial jury. ${ }^{\mathrm{x}}$ And should a person's body be so completely secure from search and seizure that it is practically impossible to convict him of carrying a concealed weapon?

Many states no longer make a fetish of a common'law grand jury. They use informations ${ }^{12}$ or a one-man grand jury ${ }^{\mathrm{x}_{3}}-\mathrm{a}$ judge trained in the art of examination. These states have not forsaken their reforms. But rllinois for serious offenses continues with its oversized, dilatory, and unnecessarily expensive and inefficient common-law grand jury.

Why should not the State of Illinois be permitted to use the deposition' of a witness in a criminal case when the witness is not likely to be available for testimony at the trial? ${ }^{14}$

. ${ }^{8}$ Illinois-A Descriptive and Historical Guide 89-92 (1939); 5 Centennial History of Mllinois $193-96$ (1920). Apparently, however, there was a conflict in its editorial policy on this question during roor and 1902 .

9 Sears, Constitutional Revision in Illinois, 33 Ill. L. Rev. 2, 10 (1938).

so These include the banking amendment in 1938 and the two-thirds Gateway Amendment in 1946. It has also stated the need of a provision to prevent members of the General Assembly from accepting employment with local governments. Cf. Ill. Const. Art. 4, § I5. It has objected to the provision whereby the Circuit Court of Cook county determines the number of assistants of four specified Cook county officers. Ill. Const. Art. ro. \& 9. Cf. Sears, op. cit. supra note 9, at 8, note 9; editorials: The Gateway Amendment Fails Again, Chicago Tribune (Nov. 7, 1946); Double Liability in Illinois, Chicago Tribune (May 29, 1937); Responsible Legislators, Chicago Tribune (Nov. Io, I937). It has recently had a qualifiedly good word for the intiative and referendum. Editorial, Labor Amendments, Chicago Tribune (Nov. 9, 1946).

II Mo. Const. Art. I, § 22; Am. Law Inst., Code of Cr. Proc. § 355 and Commentaries ro26I03I (193I); Ill. Constitutional Convention Bull. 837-46 (I920).

${ }_{22}$ Mo. Const. Art. I, $\$ \S$ I6, I7; Am. Law Inst., Code of Cr. Proc. $\$$ Ir 3 , and Commentaries 4I4-43I (r93 I); Ill. Constitutional Convention Bull. 828-36 (1920).

${ }_{3} 25$ Mich. Stat. Ann. (Henderson, I938) § 28.943.

${ }^{24} \mathrm{Cf}$. Mo. Const. Art. I, § I8. In Illinois a public officer on the public payroll can refuse without penalty to testify before a grand jury concerning the conduct of his office. But in 
Are there those who believe that the Illinois method of imprisoning for debt is the wisest provision and not one of the most medieval of those existing in the United States? ${ }^{15}$

Excess condemnation as a permissible device in eminent domain procedure is socially useful and it is permitted in other states. ${ }^{16}$

What of expressing the right of labor to organize and bargain collectively and of employers to be free from certain anti-social tactics? ${ }^{27}$

Article III-Distribution of Powers-is one of our constitutional provisions that is not enforced as written. It belongs to the days before the Civil War and it would be a public calamity if it were enforced as written. Yet it remains as a justification when our courts wish to render antique judgments on separation and delegation of powers. ${ }^{18}$

Article IV-Legislative Department-needs at least one very important additional section containing the initiative and referendum. They are not an unmixed blessing but about a fourth of our states have them and, as far as is known, no state which has adopted them has retracted. Good measures have been secured and undesirable measures, forced through legișlatures by pressure groups, have been defeated by the use of them. ${ }^{19}$ The initiative and referendum are democratic in nature and should be a good tonic for a politically sick state such as Illinois.

Members of the General Assembly "solemnly swear" to support the Illinois constitution and then most of them proceed to violate their oaths by refusing to apportion the state "every ten years" for the election of state senators and representatives. This is evil business but how can it be corrected except by a constitutional convention? Nothing is more fundamental to representative democratic government than fair apportionment. Since IgrI Illinois government has been undemocratic at the source. ${ }^{20}$

New York, a public officer who refuses to sign a waiver of immunity or to answer any relevant question before a grand jury concerning the conduct of his office can be removed from his office. N.Y. Const. Art. $\mathrm{x}, \S 6$.

is Cf. Mo. Const. Art. I, § Ir: "That no person shall be imprisoned for debt, except for nonpayment of fines and penalties imposed by law."

${ }^{16}$ See Dodd, Cases on Constitutional Law I2×2 (I94I); Ill. Constitutionál Convention Bull. 455-513 (1920).

17 Mo. Const. Art. I, $\$ 29$ : "That employees shall have the right to organize and to bargain collectively through representatives of their own choosing."

${ }^{18}$ See the annotations to this Article, Ill. Ann. Stat. 214-232 (Jones, I934).

"9 Sears and Laughlin, op. cit. supra note 4, II Univ. Chi. L. Rev. 374, 440, App. B (I944); Radin, Popular Legislation in California, 23 Minn. L. Rev. 559 (1939); Ill. Constitutional Convention Bull. 65-165 (1920).

${ }^{20}$ Elson, Constitutional Revision and Reorganization of the General Assembly, 33 Ill. L. Rev. I5 (r938); Ill. Constitutional Convention Bull. 545-554 (1920). 
A constitutional plan to reapportion Illinois for the election of its General Assembly should accompany a reapportionment of the state for the members of the lower House of the Congress and a plan should be devised to force new reapportionments every ten years in the future. Other states have made progress with such plans. ${ }^{2 x}$

Equally bad, if not more so, is our unique system of so-called minority representation. This constitutional provision has made it possible to deprive the voters in about half of the legislative districts of any choice in the final election of representatives in the General Assembly. ${ }^{22}$ The reason for this unique and perverted system was one incident to our Civil War. ${ }^{23}$ What could be more ridiculous than to preserve it further?

How about an amendment of Section I5 of Article IV to prevent members of the General Assembly from receiving "any civil appointmẹnt" from a city or a county?

Section 22 prohibiting local and special laws for many purposes should be changed to harmonize with court opinions which have interpreted this section. It is a splendid thing to have a constitution that is honestly and realistically written; it is a sad thing to have it expressed in deceptive language. ${ }^{24}$

Has the constitutional method of impeachment ever been used since I87o? It would be difficult to contrive a more dilatory, cumbersome, and expensive procedure than that provided in Section 24. Experience with this method in the Congress has been far from satisfactory. There is proof that the method results too often in political considerations affecting the verdict. ${ }^{25}$ Trials should be conducted by judicial and not by law-making

${ }^{2 x}$ Ark. Const. Amend. 23, I Digest of Stat. of Ark. I95 (Pope, I937); Mo. Const. Art. $3, \S 7$.

$\approx$ See the condemnation of this plan as it has worked in practice by Wallace Heckman in Proceedings of Ill. State Bar Ass'n, Part I, 60 (IgOI). Cf. Ill. Constitutional Convention Bull. 538-544 (r920).

There is a defense of the Mllinois method by Hyneman and Morgan, Cumulative Voting in Illinois, 32 Ill. I. Rev. I2 (I937). The argument by Hyneman and Morgan is that the Illinois method favors the return of experienced legislators. Granting that to be true, experience is only one of many desirable qualities, and everlasting experience is no adequate substitute for a failure to have a choice at the final election in about half the districts and only a limited choice in practically all of the remaining districts.

${ }^{23}$ At p. I2 of the Illinois Constitution Annotated by Prof. C. W. Tooke of the University of Illinois, appears the following: "Mr. Medill's real purpose in advocating this measure, as set forth in a letter to the writer shortly before his death, was to destroy the sectional feeling that then [ $187 \mathrm{O}$ ] prevailed in the State, a purpose that this method has well attained."

${ }_{24}$ The Illinois statutes, for example, have many provisions which actually apply to Chicago alone; but the language is, for example, that the provision applies to all cities over 500,000. See Kerwin, The State Constitution and Our Local Government, 33 Ill. L. Rev. 32 (1938).

25 tenBroek, Partisan Politics and Federal Judgeship Impeachment since 1903, 23 Minn. L. Rev. I85 (1939). 
bodies. Then there should be another method of removing officers, particularly judges, for disability without reflecting upon the honor of the officer. ${ }^{26}$

Section 34, the Chicago amendment, is sadly out of date and is a challenge to anyone to produce a worse example of draftsmanship. It also raises a serious question whether the local governments in Mlinois are entitled to a far greater measure of home rule. It is believed that other constitutions have solved this problem much more satisfactorily. ${ }^{27}$

Article V-Executive Department-can be improved. There is no logical justification for the election of a state treasurer, secretary of state, ${ }^{28}$ or attorney-general. Observe the national government. There is even less justification for the election of a superintendent of public instruction. With the appointment of these officers by the Governor, Illinois could hope to have a responsible state administration rather than an exhibition of the executive power divided among political prima donnas, each seeking to satisfy his own ego, and with the group frequently working at cross purposes. Does this give too much power to the Governor? If so, prohibit him from succeeding himself in office as in other states. ${ }^{29}$

In addition, the simple New York constitutional provision for a civil service system has been a valuable protection. Its essence has been copied elsewhere. ${ }^{30}$ Illinois would thus make a start toward a short ballot where only important policy-making officials would be popularly elected.

Section I6 concerning the Governor's veto, if not reformed, should be at least changed to accord with the approved legal interpretation of it and the administrative practice concerning it. ${ }^{3 x}$

Article VI-Judicial Department-is so completely defective that only a thorough revision of it will satisfy. A casual reading of it will disclose its antique nature. Judges of the Supreme Court should not be popularly elected; nor should the state be divided into districts for their selection. But if districts are to be retained the present hideously unequal districts should be abolished. Illinois certainly needs a judicial reapportionment.

${ }^{26}$ See Mo. Const. Art. 5, $\$ \$ 25,27$, Art. $7, \S \S 1-4$; Conn. Const. Amend. 12; N.Y. Const. Art. 6, $\$ \S 9$, 10, 17, Art. 19, $\S$ rg.

${ }_{27}$ Mo. Const. Art. 6. See Kerwin, op. cit. supra note 24, at 34 ; Ill. Constitutional Convention Bull. 377-448 (1920).

${ }^{28} \mathrm{New}$ York does not popularly elect its secretary of state, treasurer, or a superintendent of public instruction. N.Y. Const. Arts. 4 and 5 .

${ }^{29}$ Mo. Const. Art. 4, \& I7: "The governor and state treasurer shall not be eligible for election as their own successors." Ga. Const. Art. 5, $\$$ I (I). See DeLong, State's Rights and the State Executive, 33 Ill. L. Rev. 42 (1938); Ill. Constitutional Convention Bull. 621-7I5 (I920).

${ }^{30}$ N.Y. Const. Art. 5, § 6; Kan. Const. Art. 15, § 2; Ohio Const. Art. 15, § ro.

${ }^{2}$ Elson, op. cit. supra note 20 , at 29 . 
The present constitution contemplates new districts "upon the rule of equality of population. ...." That is another mirthless joke.

The clerk of the Supreme Court is elected at general elections. That is a striking example of what makes the Illinois ballot disgustingly long. The theoretically sensible procedure is to provide nothing concerning the clerk on the assumption that legislation will provide for his appointment. However, if the General Assembly cannot be trusted to do this, the constitution should provide for his appointment by the court..$^{32}$

It is in Cook county that the judicial machinery is in particularly bad condition. Rural areas appear to be satisfied in the main with the popular election of judges. But in Chicago, judicial elections are usually a farce. To begin with, the candidates, except for a tendency to keep on electing sitting judges, usually without regard to their record, age, or mental condition, are selected by the party bosses. Often, by the device of coalition the voters have no choice at the election. This is a fundamental defect; excellent judicial service without excellent judicial personnel is impossible. ${ }^{33}$

Then there is at present in Tllinois no well co-ordinated judicial system directed by a chief who can assign judges, without regard to so many different courts, where they are needed. Even a system for Cook county alone would be a worthy accomplishment. ${ }^{34}$

The popular election of justices of the peace, police magistrates, constables, and numerous court clerks serves no good purpose because rarely is the mass of voters interested in them. It serves the bad purposes of lengthening the ballot and of inviting political machines to do their tricks. ${ }^{35}$

Section 30 for the removal of judges from office is of no appreciable value. Has it ever been used? Comments concerning impeachment are applicable here. ${ }^{36}$

Article VII-Suffrage-needs to be reformed to eliminate the obsolete language and to remove the narrow restriction that no office can be filled

${ }^{32}$ Mo. Const. Art. 5, $\S 26$, contains only this sentence: "Appellate and probate courts shall appoint their own clerks." Why were the clerks of the trial courts omitted?

33 California and Missouri have adopted new systems of appointing many of their judges, particularly appellate judges, and these systems have given general satisfaction. Cal. Const. Art. 6, § 26; Mo. Const. Art. 5, $\$ 29$ (a)-29(g).

${ }^{34}$ See Mo. Const. Art. 5, §6: "The Supreme Court may make temporary transfers of judicial personnel from one court to another as the administration of justice requires, and may establish rules with respect thereto"; Ill. Constitutional Convention Bull. 725-896 (I920).

35 Missouri appears to have made a considerable improvement upon the ancient fee-collecting justice of the peace system. Mo. Const. Art. 5, $\$ \S$ I8-2r, 24.

${ }^{36}$ See note 26 supra; Ill. Constitutional Convention Bull. 822-24 (I920). 
by a person who has not resided in this state for "one year next preceding."

Article VIII-Education-could be improved in three respects: (I) providing for a non-elective board of education which will select a superintendent of public instruction on a merit basis on indefinite tenure; ${ }^{37}(2)$ providing for a similar plan for the selection of county superintendents of schools; and (3) providing for the appointment rather than the popular election of the trustees of the University of Illinois. ${ }^{38}$ Very few voters know anything about the superintendent of public instruction or the trustees and their election by parties is meaningless, when not harmful. This would be another method of shortening our ballot.

Article IX-Revenue-contends with Article XIV as the most restrictive of social progress. It has been the subject of endless criticism. Four direct attempts have been made to reform it and it has been the main reason for the five attempts to obtain a gateway amendment. Detailed discussion seems unnecessary. If one is cynical and selfish he can join with the present-day Chicago Tribune and yell "income tax"-period. But a tolerant and progressive person cannot avoid a conviction that Article IX causes unnecessary perjury, discrimination, and much social confusion and frustration. Furthermore, the main reason that we manage to tolerate this article is that officials do not faithfully comply with its requirements. The article is a blight on progress and an unfortunate reflection of our lack of first rate political intelligence. The reading of other modern state constitutions and our national Constitution as interpreted by the courts should be sufficient to prove this. ${ }^{39}$

Article X-Counties-should be compared with Article VI of the Missouri constitution of 1945 . Then what Illinois has and does not have in the way of modern local government will be appreciated. The election of fifteen commissioners for Cook county as required by Section 7 is excessive by at least twelve. Provisions for home rule by cities and counties and for the consolidation of local governments are missing from the Illinois constitution. A modern article on local governments could be a profitable investment for Illinois. ${ }^{40}$

${ }^{37}$ See Mo. Const. Art. 9, § 2. ${ }^{38}$ See Mo. Const. Art. 9, § 9 .

39 Illinois is now apparently one of only five states "retaining the archaic provision in its tax structure that all property-real, personal, and intangible-must be assessed and taxed at the same rate." Missouri Adopts a New Constitution, 30 Bull. Nat. Tax Ass'n No. 6 (1945). See Illinois Constitutional Requirement of Uniformity in Taxation, 33 Ill. L. Rev. 57 (1938); Mll. Constitution Convention Bull. 215-33I (I920).

${ }^{40}$ See Kerwin, op. cit. supra note 24, at 4 I ("What it [Illinois constitution] does not provide is a modern guarantee of Home Rule-a guarantee now found in practically all the constitutions of the populous states."); Ill. Constitutional Convention Bull. 905-ro76 (1920). 
Article XI-Corporations-contains highly restrictive provisions on state banks. An attempt was made in I 938 to abolish them and to adopt the policies of other states and the national government. But that amendment was not adopted, despite much publicity and practically no opposition, because the non-voters automatically were counted as negative voters. Thus, the growth of the state banking system is seriously handicapped. Perhaps that is a matter of no appreciable importance except to the small communities, but it is time to unblock, and cast out some antique language. ${ }^{4 \mathrm{I}}$

Is there any necessity for the retention of Article XII-Militia-or Article XIII-Warehouses? Are not these examples of ordinary legislation unnecessarily placed in a constitution?

Article XIV-Amendments to the Constitution-is fundamentally defective. It has a cancer that requires an operation. This has been explained and demonstrated so frequently that the Illinois citizens who can be unaware of it are those who are not interested in political problems on the state level. A requirement that a constitutional convention or constitutional amendment must secure for adoption a majority of all the votes cast for any measure or any person in a general election is practically unworkable as long as so many voters refuse to vote on constitutional propositions. In addition, the restriction upon the General Assembly that forbids the proposal of "amendments to more than one article . . . a the same session" is beyond rational justification. Most states place no limit on the number. ${ }^{42}$

This statement of urgent reforms is not exhaustive. It is intended to state the most obvious and pressing requirements for a modern and useful constitution. For, be it remembered that a Republican political scientist writing in May, I938, announced: "The state [Illinois] would probably be better off than at present if it simply repealed its constitution and operated with none at all." 43 (r939).

4I Sears, The Illinois Constitution and the Banking Amendment, 6 Univ. Chi. L. Rev. 234

From information supplied by F. A. Adams, Chief Bank Examiner, Springfield and Southern Division, the state banking situation is this:

Number of State Banks

Dec. 3I, I929

Dec. $3 I, I 936$

Dec. 3I, I945
$I, 28_{3}$

$5^{8} 3$

490
Total Resources

$\$ 3,265,542,839 \cdot 70$

$\$ \mathrm{I}, 264,593, \mathrm{I} 57 \cdot 72$

$\$ 3,240,326,243$. I5

${ }_{42}^{2}$ See Sears and Laughlin, op. cit. supra note 4 . Cf. Ill. Constitutional Convention Bull. I7 1 -206 (I920).

43 DeLong, op. cit. supra note 29 , at 44 . 


\section{OBTAINING A CONVENTION}

The General Assembly can block a legal constitutional convention unless "two-third of the members of each house" are willing to vote in favor of a resolution submitting the question to the voters. The record discloses that in I9I7 under the leadership of Governor Lowden ${ }^{44}$ and in 1933 under Governor Horner ${ }^{45}$ there were relatively few who voted against convention resolutions. There is no necessity to elaborate upon the failure of Governor Green's feeble effort in I945. A spiritless effort by a governor is not likely to be successful.

Under favorable conditions, which have been described elsewhere, the first resolution received an affirmative vote of 57.6 per cent of those voting in I $918 .{ }^{46}$ Thus, it carried, but the new constitution that was submitted in I922 was defeated by a terrific majority. Various explanations of this defeat have been presented. It is believed that the most potent were: (I) the submission of the document as a unit rather than by articles or sections, which would have secured a separate vote on controversial propositions; (2) the belief in Cook county that the downstate majority in the convention had driven a hard bargain on reapportionment and had thus treated Cook county unfairly; and $(3)$ the prevailing political reaction which had spread over the country by 1922.47

The second proposal was submitted in I934. The campaign for it was a modest effort; it was not a high-pressure affair. Yet, the proposal received a majority of 105,I42 of those who voted on the proposal. It was not adopt-

44 Ill. S. Jour., at 25I, 265, 274 (I9I7); IIl. H. Jour., at xo6, 143,323 (xgI7). A vote on a convention was authorized by Senate Joint Resolution No. 1 , introduced Jan. I6, I9г7, and passed by the Senate on Jan. 24 by a vote of 46 to I. It was passed by the House on March I4 by a vote of $I 12$ to 30 . It is to be remembered that less than a month thereafter we were in World War I. This may account for the number in the House who voted nay on March 14, 1917.

45 Ill. S. Jour., at 47-50, 67, 295, 636 (1933); III. H. Jour., at I33, 518 (I933). The resolution for a vote on calling a constitutional convention passed the Senate by a vote of 36 to 0 . Among those voting yea were Richard J. Barr of Joliet and James O. Monroe of Collinsville. In the House who moved that the House concur in the resolution? None other than the ardent Republican conservative and ally of Robert R. McCormick, Elmer J. Schnackenberg. The vote was II 8 yeas to only 5 nays. Two of the nays were cast by the somewhat fanatically partisan Clinton Searle of Rock Island and by R. G. Soderstrom, then of Streator and now president of the Illinois Federation of Labor. This seems to go far to explain the continued hostility of the Federation to a convention. There was no war in 1933 but there was a depression. Conditions never seem to suit Mr. Soderstrom.

${ }^{46}$ Sears, op. cit. supra note 9.

47 See Dodd, Illinois Rejects a New Constitution, 7 Minn. L. Rev. I77 (1923); Davis, Defects and Causes of Defeat of the Proposed Constitution of 1922,26 Chicago Bar Record 276 (1945). 
ed because 56.5 per cent of those voting in the r 934 election failed to vote on the constitutional proposal..$^{8}$

\section{VOTING ON CONSTITUTIONAL PROPOSALS}

Voting on constitutional proposals after the adoption of the little (separate) ballot in 1899 through the first two decades of the twentieth century gave some hope that the Illinois method of voting was not practically hopeless. During this period one amendment, one bond issue submitted as an amendment, and a convention proposal were adopted. The percentage of non-voters in those years ranged from $24 . x$ to 29.5 per cent. Since then the results under both the little ballot and the Emmerson law, which placed constitutional proposals on the main candidates' ballot in the first column, have been unvarying and depressing. All propositions, nine of them, have failed of adoption. Only one of them was defeated because a majority of those voting on the particular proposition were against it. The others failed merely because from 6 I.95 to $4 \mathrm{I}$ per cent of the voters failed to vote on the propositions. And on the single defeated proposition 62.I per cent of the voters failed to vote. ${ }^{49}$

Frequently it has been explained how very different were the results in the period prior to the adoption of the Australian ballot act in Illinois in I89r. During that period the voters adopted every constitutional amendment that was presented. The non-voters on these five successful amendments varied from $x 7.1$ to $3^{1.6}$ per cent. ${ }^{50}$ What explains this difference? The answer lies in the nature of the private and party ballots used prior to I8gr and the official state ballot containing all party nominations and constitutional proposals on a single sheet of paper which was used after I89I until 1899 and then again after $1929 .{ }^{5 \mathrm{x}}$ The private and party ballots prior to I8gr permitted the maker of a ballot to print only the affirmative of a constitutional proposal on his ballot. If 'this ballot was deposited in the ballot box without alteration it was a vote for the constitutional proposal, whether the voter was aware of it or not. Likewise, the maker of a ballot prior to $189 \mathrm{I}$ could have printed only the negative of a constitutional proposal with a similar result. The writer has never seen this latter

${ }^{8}$ Sears, op. cit. supra note 9 .

49 Sears and Laughlin, op. cit. supra note 4 , at ${ }_{5} 5$. The vote on the amendments submitted in 1944 and 1946 was obtained from the secretary of state. Votes upon amendments are customarily printed in the Illinois Blue Book.

${ }^{50}$ Ibid.

sx Tbid.; Sears, op. cit. supra note 9; Sears, Horse and Buggy Government, Chicago Sunday Times, p. 6 (April 30, 1939); Sears, Constitutionality of Party Circle Bills, r3 Univ. Chi. L. Rev, 52 (I945). 
type of a ballot, but has seen the former in at least two scrapbook collections. There is also a third type of ballot in these collections. This type has both the affirmative and the negative statement of the constitutional proposal and required a voter to draw a line through one statement; otherwise he would be a non-voter and thus under the Illinois constitution an automatic negative voter. The maker of a ballot before $189 x$ could also have omitted all statements concerning a constitutional proposal from his ballot, and one apparent example of this type of ballot is known to exist.

In an article that was printed in the Chicago Times in $1939^{52}$ there are photographic reproductions of four ballots printed prior to I8gI. These ballots were found in the scrapbooks of Charles Spencer Harpel who in his lifetime was an officer of the Chicago Historical Society. His scrapbooks now belong to that institution. These ballots are proof enough how the methods of voting prior to $189 \mathrm{x}$ made it relatively easy to adopt constitutional proposals in Illinois in that period, if the party leaders were generally in favor of them. The indifference and ignorance of so many voters on such proposals were turned into affirmative votes rather than permitted to be counted as negative voters. This was the method of voting known to those who drafted the constitution of 1870 and they did not contemplate the very different method of voting adopted twenty-one years later. Thus, in a practical sense the method of amending the 1870 Illinois constitution was completely revolutionized as an unexpected by-product of a reform in the ballot law in r8gr. What had been a relatively easy method of adopting amendments became an impossible method under the ballot law existing from 1891 to 1899 , a difficult method under the little (separate) ballot law from 1899 to 1918 , and a total failure under both the little ballot and the Emmerson laws from I924 to date. And indifference and ignorance as to constitutional proposals seem to have greatly increased in the last three decades. Why, is not entirely clear.

\section{ADDITIONAL BALIOTS PHOTOGRAPHED}

Recently, Judge George C. Dixon, of Dixon, Illinois, formerly a member of the Illinois General Assembly, discovered that one of his family scrapbooks contained a large number of pre-I89 I ballots. Some are ballots for local elections and some are ballots of other states. He kindly sent this scrapbook to the author. It was made by his cousin, William D. Barge, who was an assistant corporation counsel of Chicago for about twenty years. Later he was in the law department of the Chicago, Burlington \& Quincy Railroad Company, and still later in private practice.

\footnotetext{
${ }^{52}$ Note 5I, supra.
} 
In this scrapbook are eight ballots which state only the affirmative of constitutional amendments submitted to Illinois voters at various elections prior to I89I. Two were Republican ballots, one of which is reproduced. Four were Democratic; there were also one Greenback and one Prohibition. Voters using this type of ballot would vote for the amendment, which appeared on the ballot below the names of the candidates for office, unless they were careful to observe the statement for the amendment and then draw a line through that statement.

The opposite type of ballot-stating only the negative of a constitutional amendment-was not found in either the Dixon or the Harpel scrapbooks. But in the Dixon scrapbook is an.interesting National Union Labor Ticket which has as its last item their statement: "Against the General Banking Law," and no affirmative statement of the proposition.

A third type of pre-I8gI ballot was that which left the constitutional proposal "open," i.e., the maker of the ballot made no decision in favor of or against the proposal. Accordingly the proposition was printed in at least three forms.

(I) For Proposed Amendment to Section Sixteen of Article Five of the Constitution. Against Proposed Amendment to Section Sixteen of Article Five of the Constitution.

(2) For, or against, Proposed Amendment to Constitution.

(3) For Against

Constitutional Amendment

There are eight ballots of this general type in the Dixon collection. They disclose their private nature by the fact that in Lee county in I886 James $\mathrm{H}$. Thompson and George D. Laing were candidates for county clerk. Thompson's name alone appeared on one ticket, that was apparently a Republican ticket. His name alone appeared on three Democratic tickets. Yet, the name of George D. Laing alone appeared on one Republican and one Democratic ticket. On the latter his name was on a slip of paper which had been glued on the ballot. It is a fair guess that this slip was pasted over Thompson's name.

In the Dixon scrapbook is a letter on the stationery of the "Headquarters Republican State Central Committee." It is dated "Chicago, November Ist, I888" and is above the name of "James S. Martin, Chairman." Part of the letter follows:

BEWARE Of Pasters. The Democrats have sent all over the State little books of Pasters with Palmer's name on them, hoping to get them pasted over Fifer's name on the tickets. Look after this sharply.

Look out for Tickets headed with the names of the Republican candidates followed by the Democratic Electors..... 
ifs

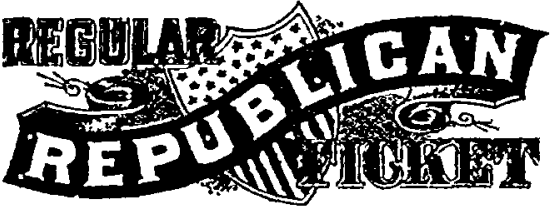

For Stato Treasurer, FRANZ ATBBHRG.

For State Superintendont of Public Instruction, RICEARD ISDWARDS.

For Trusteas of the Un'versity of Illinors, CEARTAT8 G. NERTST.

WIITIS A YANGEIHTD. CHARLER BENTIETT.

For Clork of the Supreme Court, Northern Grand Division, ALFTHD H. TAYLOR.

For Representative in Congress, First Congressional District, ABNLAR TAYLOR.

For State Sonator, Third Senatoriat District, GEORGE BASS.

For Representalives, Third Senatorial District, JOHN C. WATTACE-1's Votes.

EDWARD E. MORRIS-14 Votos

For County Judgo of Cook County, EDWARD KAEIRR

For Prohate Judgo of Cook County, CERISTIAN G. KOBLSAAT.

For Judge of the Suparior Court of Cook County. (to succeed
Gwynn Garmett), THEODORE BRENTANO.

For Judge of the Superior Court of Cosk County, (to succeod Egbert Jamieson).

For Shorift of cook County. JAUES ㅍ․ GIIBERT.

For Counly Treasurer of Cook County, LOUIS HUT"T.

For County Clerk of Cook County. HUENRY WULFF.

Fur Clork of the Probale Cuurt of Cook County. THOMLS W. SENNOTT.

For Clark of the Criminal Court of Cook County. PETER A SUNDELTUS.

For Clerk of the Appollate Court, First District. JOEN J. MCEENINA.

For County Superintendent of Sthools of cook County. ALBERT G. LANE.

For President of the Board of Commussioners of Cook County. IEWIS P. HARVEY.

For Memuars of the Board of Cominissioners of Cook County to be Electeci Irom the City of Chicago, LEWIS P. HARVEY. DANTEL J. WEREEE. ELI SXITE VALENTLLE EOPF. JAMTES CONROYD. WILLIAM HI DURANT. JOEN BLEGEN.

JAMES SKALTERUP.

MICEAEL UMDDENSTOCK.

CEARLES I. ORIEBENOW.

\footnotetext{
For the Amendments to the Act cancarning Corporations with

For proposed Amendment to Articlo 9 of the Constitution. For Annexation of the Village of Fornwood to the City of for Annexation of the Village of Washington Heights to the City of Chicago.

For Annexation of the Village of Wiest Roselend to the City of Chicago.

For Issuing the Bonds by the South Park Conimlssioners.
}

(H)serve the six closcly printed propositions, all of which are stated in the allirmative. It would have been very dificult to have drawn a line through the constitutional amendment and then lave written the negative of the propnsition with a pencil or pen without defacing the ballot. To be sure, a line through the aftirmative would have amounted to a negative but how many voters were aware of that?

\section{REPUBLICAN TICKET.}

For State Treasurer.

JOHN R. TANNER.

Superintendent of Public Instruction,

\section{RICHARU EDWARDS.}

For Representative in Congress. Seventh Congressivusl District.

THOMAS J HENDERSON.

For State Senator, 19tl Senutorial District,

JOHN D. CRAB'LREE

For Represontative, 19th Senstorial District.

JOHN W WHITE; $1 \frac{1}{2}$ 7O1es.

BENJAMIN H BRADSHAW; $1 \frac{1}{2}$ votes.

For County Judge,

JAMES B. CHARTERS.

For County Clerk.

GEORGE D. LAING.

For Sherifr,

WILLIAM H. WOODYAT"T.

For County 'I'reasurer.

CHARLES H. HUGHES.

For County Superintendent, ABRAM ACKEK'T.

For, or agrinst, Proposed Appropriation for Soldiers' Monument.

For, or against, Proposed Anendment to Constitution.

Observe that the constitutional amendment is the last item on this ballut and therefore the least likely to be seen by the voter. If the proposition were left alone it would amount to an automatic negative vote.
NATIONAL UHION LABOR TIGKET

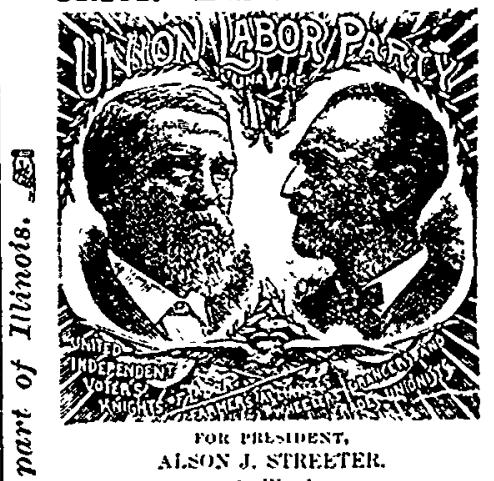
of llinois.

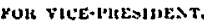
CHARLES F. CLNINGHAM of irhateds.

Premlicutlal Hlectorn-at-Larze.

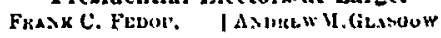
Distrlet RElectorm.

Walter Willay, Johx b Hrinur,

JuHN B. BENNist, J. F, LAXE,

Jahs H. Rasigale, H. A. Prospotr,

Behxahd firese, Dasiel. L. Braccuer,

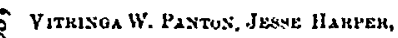

Jorx Beblosio, CE (ial,woul,

TIYOTHY SAXMUSY, EnWAHD ROERSLE,

l. C. SHvMaker, II. C. Bolohan,

O. W. Bagsaro, Hevky F KaLnу⿰н, JoHN H. ABYSTKUNO, SOHN DTPONT

Btate Ticket.

ron uoveniok, WILLIS W. JOXES.

YOK LIMUTEXAXT WOYERXUH, JODS M. FOLET.

TOK MZCHETAKY OP STATE, LLOYD W. ROBERTSOY.

TOR AUVITOH OF STATE GEOKGE W. COLLINS.

FOH THRASURER,

NATAAN BARNETT

TOR ATTOHNET +GENERA

JAMES M. DILL.

FOK THLUTEXS ST ITE TSIYEKSITY, L. L. DE.A.T-Six Years.

A. H. STEVEXSU.N-Six Years.

w. T. WALLACE-S.x Yoare.

J. W. LANE-Tho Yerara.

YOH REPKESEYTATIV N NOVOKEY,

POR MLMBEH CF THE STATE HOAHE ON

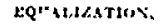

PUR STATE \&ES

POH HEYKLYENTATISE IS THE WEXAKAL ASSEMIIS, Turee votes.

Connty Ticket. YOR BRATES ATTOHSLE,

FUK CTHLLIT I H.LK

Fuls colouspis,

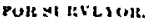

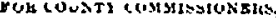

Agalogt the Gederal Banklng Latr.

Apparently this ballot was printed in a n(wisajer or as a part of campaign lit (eralure. ()bserve 1 ! the in struction on the margin of the ballot and 12 i the negif tive statement only of the bankins proposition. 
SPECIMEN BALLOT.--4th Congressional District, 6th Senatorial District. I

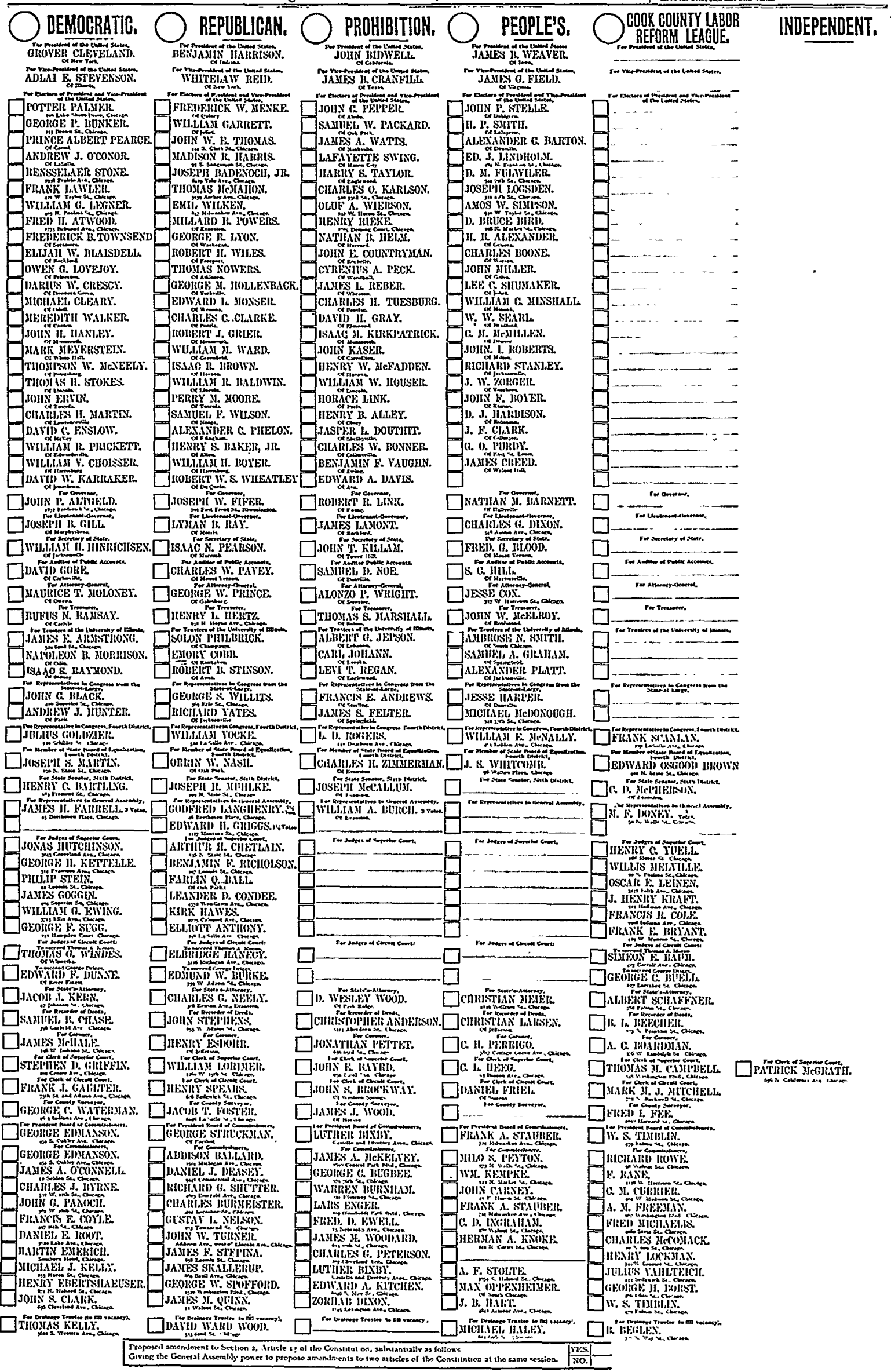

This is a sample of the first oficicial ballot used in Illinois. Observe the inconspicuous position of the first Gateway tmendment and then the fact that $79.6 \%$ of the voters failed to vote on the amendment ceases to be a surprise. But all of these failures were counted as automatic negative votes. 
It was possible before $I 89 \mathrm{r}$ in Illinois for any person or party group to print a ticket that simply ignored the constitutional amendment that was before the voters. The use of such a ticket by a voter would have resulted in an automatic negative vote on the proposal unless he used a paster or wrote on the ballot some such expression as "For Constitutional Amendment." In the Dixon scrapbook is one such ticket, the People's Ticket, that was apparently distributed in Lee county in I884.

Finally, the Illinois Australian Ballot Act was passed in I8gI and at the next general election in 1892 , Illinois for the first time used, not any sort of a ballot that anybody wished to prepare, but an official ballot that had party columns for all parties on one sheet of paper. The Dixon scrapbook contains a printed sample ballot used at this 1892 election. It is a large ballot nearly twenty-five inches long and nearly sixteen inches wide. At the bottom of this ballot, underneath the party columns, appeared the first so-called Gateway Amendment. The General Assembly evidently did not understand voters very well, if they expected them to find and individually vote upon an amendment at the bottom of such an unwieldy ballot. Only 20.4 per cent of the voters expressed themselves; $79.6 \mathrm{per}$ cent did not vote on this amendment. ${ }^{53}$ Thus Illinois floundered into a constitutional morass and it is still there.

\section{CONCLUSION}

Governor Horner nearly had Illinois out of its morass in 1935. But one week-end Robert R. McCormick and Mayor Kelly, ${ }^{54}$ aided perhaps by the Chicago Daily Neres, decided that the party circle bills should be defeated. And that happened very quickly after the House of Representatives met early the next week. Benjamin Adamowski was the majority leader, but he moved that the bills be stricken from the calendar without

${ }^{3}$ Note 49 supra.

s4 It is to the distinct credit of Mayor Kelly to record the fact that his views have changed. There follows a letter he wrote to the author on Jan. 9, 1947:

"This will acknowledge receipt of your recent communication, requesting my views on two propositions recommended by your Committee on Constitutional Revision of the City Club of Chicago. These propositions are: (I) Adoption of a resolution by the next General Assembly submitting to the voters in 1948 the question of calling a constitutional convention for Illinois; and (2) adoption of the party circle in voting on this question.

"I am heartily in favor of both propositions. Our present State Constitution is antiquated. Not only are its provisions for raising revenues completely out of date so far as the City of Chicago is concerned, but its failure to provide even a minimum of local home rule makes it impossible for the City of Chicago to take the steps which are necessary to solve its most vital post-war problems. In this respect, Illinois is probably the most backward state in the union and Chicago undoubtedly legally the most impotent large city in the United States.

"Use of the party circle will make it possible to pin responsibility for support or defeat of constitutional revision on the political parties, where it should be." 
consulting with Governor Horner, whose floor leader he was supposed to be. ${ }^{55}$ Governor Green has been tepid and cold on the bills, but mostly cold. Then when the Illinois Agricultural Association gave him a surprise party, by getting the bills passed on the last night of the I 945 session, he pleased the Tribune by vetoing them. Attorney-General Barrett came up with an opinion that the bills were unconstitutional and very, very naughty in addition..$^{6}$ Then along came the Daily News, which in 1939 had changed from I935 opposition to approval, with another condemnation of the bills. What is the solution offered now by the Neres? Education! $!^{57}$ But a generation has gone to its grave and the education is getting nowhere fast. If a professor were to advocate such perfectionism, he would be laughed at as an impractical theorist. What has become of some of our hard-headed men of affairs? Are they afraid of a livino society?

ss Sears, op. cit. supra note 9, at 7. In a news article in the Chicago Daily News on June 4, 1935, Warren Phinney stated that the party circle bills were "vicious." He also quoted Rep. Adamowski as telling the House of Representatives that these bills "will look pretty only when they are dead." Oh, yes? On May 3, 1939, the same Daily News in an editorial approved the same bills. And,Adamowsiki lived to see the day when the bills were passed by a conservative Republican Senate 40-I and by the same type of a House 127-3 with Governor Green trying to prevent this action by the House. This changed editorial policy of the News continued until John S. Knight purchased control and Paul Scott Mowrer ceased to be editor.

${ }^{6}$ Sears, Constitutionality of Party-Circle Bills, $1_{3}$ Univ. Chi. L. Rev. 52 (1945); Foster, What Is This Gateway Amendment? Ill. Agricultural Ass'n Record r6 (Sept., I945): "Many of Governor Green's statements in his veto message were not in keeping with his attitude during early consideration of the legislation in the Senate and brought keen disappointment to the Illinois Agricultural Association as well as to other organizations interested in needed constitutional reform."

It may well be doubted whether even the Chicago Tribune was convinced by AttorneyGeneral Barrett's opinion. See, editorial, Yes on the Gateway Amendment, Chicago Tribune (Nov. 4, 1946): "Under the present constitution this [voting by party circle on constitutional amendments] might, perhaps, be done lawfully."

57 Editorials: Defeat This Dangerous Bill, Chicago Daily News (June 3, r935); To Break a Blockade, Chicago Daily News (May 3, I939); A Good-Bad Legislature, Chicago Daily News (July 3, I945); The Party Circle, Chicago Daily News (July 10, I945); No Party Circle, Chicago. Daily News (Aug. I, I945); No Gateway, Chicago Daily News (Nov, 7, r946); Prof. Sears' Plan, Chicago Daily News (Nov. I4, 1946). Letters to the Editor: Party Circle for Constitution Vote, Chicago Daily News (Nov. I8, I946); Amending State Constitution, Chicago Daily News (Nov. 30, 1946).

In the last election, Austin Wyman, who was in charge of the Cook county drive to secure the adoption of the Gateway Amendment, obtained a pledge from the county clerk and the board of election commissioners to instruct the precinct election officials to call to the attention of the voters the location of the Gateway Amendment on the ballot. This instruction was faithfully performed in some precincts, to say the least. The editor of the News should read a letter that appeared in the Chicago Tribune on November II, I946. An election judge complained that although she "audibly declared some 400 times" where the amendment was located, yet "over 5o per cent" failed "to vote either one way or the other." She also stated that "our precinct is located where the majority are American born and educated." 